\title{
Resolving the naturalization strategy of Solidago $\times$ niederederi (Asteraceae) by the production of sexual ramets and seedlings
}

\author{
Artur Pliszko $\mathbb{B} \cdot$ Kinga Kostrakiewicz-Gierałt
}

Received: 23 February 2017 / Accepted: 29 August 2017 / Published online: 6 September 2017

(C) The Author(s) 2017. This article is an open access publication

\begin{abstract}
In this study, the authors aimed to revise the ability of Solidago $\times$ niederederi, a hybrid between $S$. canadensis and $S$. virgaurea, to produce sexual ramets and seedlings as a part of its naturalization strategy. Based on a two-season garden cultivation experiment, we showed that the hybrid produces more generative ramets than vegetative ones and the number of generative ramets increases from one season to another with an increasing number of stem buds located on the caudices. We also revealed a spontaneous seedling recruitment by the hybrid during cultivation in the garden. Based on the seed germination test under laboratory conditions, we evidenced that the hybrid can reach a higher final germination percentage than $S$. canadensis but a lower one than S. virgaurea. Based on field studies conducted in 35 populations in Poland, the hybrid formed the largest populations in tree plantations and on abandoned fields, reaching 16.5 and 15.7 ramet clusters on
\end{abstract}

Communicated by Claus Holzapfel.

A. Pliszko $(\bowtie)$

Department of Taxonomy, Phytogeography and

Paleobotany, Institute of Botany, Jagiellonian University,

Kopernika Street 31, 31-501 Kraków, Poland

e-mail: artur.pliszko@uj.edu.pl

K. Kostrakiewicz-Gierałt

Department of Plant Ecology, Institute of Botany,

Jagiellonian University, Lubicz Street 46, 31-512 Kraków,

Poland average, respectively. The most abundant populations were found on abandoned fields; however, the mean number of ramets per cluster did not differ remarkably among habitats $(H=6.5, p=0.163)$. In all populations, the mean number of vegetative ramets per cluster reached 0.85 , while the generative ones achieved 6.43 on average. The statistical analysis proved that the aforementioned differences are significant $(t=-12.6, p=0.0002)$. Our results suggest that $S . \times$ niederederi is able to generate its own offspring by sexual reproduction and that abandoned fields seem to be the most suitable habitats for its establishment.

Keywords Abandoned field · Establishment . Hybrid - Seed germination test - Sexual and vegetative ramets $\cdot$ Solidago

\section{Introduction}

Naturalization of plants is a spontaneous process whereby introduced plant species reproduce consistently in the wild and sustain self-replacing populations over many life cycles without direct intervention by humans. Naturalized plants (also known as established plants) do not necessarily invade natural, seminatural or anthropogenic habitats, and they recruit offspring usually close to adult plants (Richardson 
et al. 2000). According to Pyšek et al. (2004), to be classified as naturalized, an alien plant must sustain self-replacing populations for at least 10 years. The ecological background of naturalization is related to disturbance, availability of resources (nutrients and moisture), and interactions with resident biota (competition, mutualism, and herbivory) (Richardson and Pyšek 2012). Due to human activities and changes in ecosystems, $3.9 \%$ of the global flora has established self-sustaining populations in regions outside of its native range (van Kleunen et al. 2015). Interestingly, Richardson and Pyšek (2012) suggested that habitat type affects the probability of naturalization partly because species arrive in new areas preadapted to certain habitats in their native ranges. This statement needs to be reconsidered in the case of hybrids between alien and native species that can inherit adaptations to habitat from a native parental species. Following the concept by Pyšek et al. (2004), hybrids between alien and native plants should be treated as alien species, and consequently they can be considered as introduced, naturalized, and invasive.

Solidago $\times$ niederederi Khek (Asteraceae), a spontaneous hybrid between the North American S. canadensis L. s. 1. and European $S$. virgaurea L. s. str., has been reported from several countries in Europe, including Austria, Italy, the United Kingdom, Germany, Denmark, Sweden, Norway, Poland, Lithuania, Latvia, and Russia (Pliszko 2015; Gudžinskas and Petrulaitis 2016; Pagitz 2016; Pliszko and Zalewska-Gałosz 2016). It occurs in some of the typical sites in which $S$. canadensis is found as naturalized or invasive, including abandoned fields, roadsides, railway embankments, ruderal ground, disused quarries, and tree plantations (Nilsson 1976; Burton 1980; Sunding 1989; Pliszko 2013; Stace et al. 2015; Pliszko and Zajac 2016). It was also reported from arable field within a grass-legume mixture (Pliszko and Jaźwa 2017). It forms characteristic clonal clumps of stems similar to those of $S$. canadensis L. and S. virgaurea. As a hybrid of two long-lived perennial plants, $S . \times$ niederederi most likely has a potential for long persistence in the wild by underground caudex. However, there is no evidence that the hybrid (at least $F_{1}$ generation) forms long rhizomes typical of $S$. canadensis. What is interesting is that the hybrid is not totally sterile (Nilsson 1976) and can reproduce generatively by wind-dispersed achenes. However, the fruit set in the hybrid is limited due to its reduced pollen viability (Migdałek et al. 2014; Karpavičienė and Radušienè 2016). According to Nilsson (1976) and Pagitz (2016), S. × niederederi shows self-incompatibility and thus its generative success depends on the presence of mating partners (including the parental species) and pollinators. Field observations in Poland have shown that the hybrid attracts many insect pollinators and therefore can pose a threat to native $S$. virgaurea since its pollination biology promotes backcrossing and introgression (Pagitz 2016).

The first report on the establishment of $S . \times$ niederederi was provided by Nilsson (1976) who found the hybrid in a few localities in Sweden and Denmark. Recent data from Austria and Lithuania indicate that $S . \times$ niederederi forms locally established populations, associated with the parental species (Pagitz and Lechner-Pagitz 2015; Gudžinskas and Žalneravičius 2016; Pagitz 2016). In Poland, $S$. $\times$ niederederi is known from several dozen localities (Pliszko and Zając 2016) and its naturalization is under consideration. It has been observed since 2011 in Mieruniszki, north-eastern Poland (Pliszko 2013), where it first started growing probably in 2009, which suggests that it can easily survive in the wild during a few seasons or even longer. Unfortunately, there is no information that would explain clearly whether the hybrid can be established by vegetative or generative reproduction. Taking into account that $S . \times$ niederederi can be constantly provided by repeating hybridization between its parental species at the same occupied locality for proper interpretation of naturalization (Richardson et al. 2000; Pyšek et al. 2004), it is important to confirm that the hybrid is able to produce own offspring (vegetative or generative). In this study, therefore, we aimed to revise the ability of $S$. $\times$ niederederi to produce sexual ramets and seedlings as a part of its naturalization strategy, testing the following hypotheses: (i) after physical fragmentation of a single clone the number of generative ramets increases from one season to another with the number of stem buds located on the caudices, (ii) the ramet clusters include more ramets in hybrid populations occurring on abandoned fields than in other habitats, (iii) the share of generative ramets in ramet clusters is higher than vegetative ones in hybrid populations, and (iv) the hybrid seeds germinate with a lower percentage than seeds of its parental species. 


\section{Materials and methods}

\section{Garden experiment}

A single clone of Solidago $\times$ niederederi, which was composed of a cluster of rooted caudices with stem buds (resting buds), was dug out from an abandoned field near Suwałki (GPS coordinates: $54^{\circ} 04.480^{\prime} \mathrm{N} /$ $22^{\circ} 56.925^{\prime} \mathrm{E}$; altitude: $174 \mathrm{~m}$ a.s.l.), north-eastern Poland, on April 28, 2015. Next, the cluster was divided into separated caudices and the stem buds on each caudex were counted and measured. A total of 16 caudices were selected and manually arranged by the number of stem buds (excluding the caudices on which the stem buds were longer than $1 \mathrm{~cm}$ ) to create four groups of four fragments of the cluster as follows: (A) fragments with no stem buds, (B) fragments with one stem bud, (C) fragments with two stem buds, and (D) fragments with three stem buds. On the same day, all the prepared fragments of the cluster were planted in two rows at intervals of $0.5 \mathrm{~m}$, in a sandy, mesic soil, in a small domestic garden $\left(25 \mathrm{~m}^{2}\right)$ in Garbas Pierwszy (GPS coordinates: $54^{\circ} 09.733^{\prime} \mathrm{N} /$ $22^{\circ} 37.145^{\prime} \mathrm{E}$; altitude: $183 \mathrm{~m}$ a.s.l.), north-eastern Poland. The hybrid was cultivated during two seasons to investigate its ability to form vegetative and generative ramets, being irrigated manually with no fertilization. Moreover, the hybrid was available for wild pollinators to enable its sexual reproduction. The area of the garden was also under a manual weed removal system to eliminate the competition with other species and to increase the chance of hybrid seedling recruitment. The viability of hybrid seedlings (leaf rosettes) was estimated visually based on leaf morphology features (Nilsson 1976; Gudžinskas and Žalneravičius 2016).

\section{Population sampling}

Field surveys were conducted in six regions in Poland in August, September, and October 2016. A total of 35 populations of Solidago $\times$ niederederi were sampled from six different types of habitats, including 25 populations from abandoned fields, five populations from roadside slopes, two populations from tree plantations, one population from a forest clearing, one population from a roadside ditch, and one population from a disused limestone quarry. The majority of the recorded habitats exhibited mesic sandy or clay soils and were created by humans 5-10 years ago (Table 1). Moreover, all the habitats were co-occupied by $S$. canadensis and $S$. virgaurea, representing disturbed cover of vegetation. The abandoned fields, roadside slopes, roadside ditches, and tree plantations were dominated by species typical of meadow, ruderal, and agrestal plant communities (Molinio-Arrhenatheretea, Artemisietea vulgaris, and Stellarietea mediae, respectively), whereas the disused limestone quarry was dominated by species typical of xerothermic grassland and ruderal plant communities (Festuco-Brometea and Artemisietea vulgaris), and the forest clearing was dominated by species typical of woodland clearings plant communities (Epilobietea angustifolii). Within a sampling area of 0.5 ha for each population, the size of the population based on (i) the total number of clusters of mature ramets and (ii) total number of ramets was considered. We excluded from the consideration young vegetative plants, which are difficult to recognize in the field, defining the hybrid individual as a visually separated cluster of mature ramets (generative/sexual and vegetative/asexual stems). The hybrid was identified using morphological features provided by Nilsson (1976) and Gudžinskas and Žalneravičius (2016).

Fruit sampling and seed germination test

Achenes of Solidago $\times$ niederederi and its parental species were collected from a disused limestone quarry in Kraków (Mydlniki), southern Poland (GPS coordinates: $50^{\circ} 05^{\prime} \mathrm{N} / 19^{\circ} 50^{\prime} \mathrm{E}$; altitude: $225-243 \mathrm{~m}$ a.s.1.), on October 9, 2016. For each species, 10 panicles with mature fruits were randomly sampled. Next, the panicles were threshed manually inside a paper bag to obtain a mixture of fruits for further analysis. For each species, sets of 50 achenes in four replications were randomly selected from the samples visually identified as well-developed fruits (with no deformation and damage), using a PZO Warszawa 18890 stereoscopic microscope. Achenes were stored for 172 days in plastic zip lock bags, in a dry, dark room, at a temperature of $+25^{\circ} \mathrm{C}\left( \pm 5^{\circ} \mathrm{C}\right)$. Following Baskin and Baskin (2014), sets of 50 achenes in four replications were mixed with $50 \mathrm{~g}$ of dry sand and placed in 9-cm-diameter polystyrene Petri dishes. Next, the substrate, which was distributed uniformly in the dishes in a thickness of about $0.3 \mathrm{~cm}$, was wetted 
Table 1 Origin and habitat characteristics of Solidago $\times$ niederederi populations sampled for the study

\begin{tabular}{|c|c|c|c|c|c|}
\hline \multirow[t]{2}{*}{ Region } & \multirow[t]{2}{*}{ Locality } & \multirow{2}{*}{$\begin{array}{l}\text { GPS coordinates and } \\
\text { altitude }\end{array}$} & \multicolumn{3}{|l|}{ Habitat } \\
\hline & & & Type & $\begin{array}{l}\text { Soil moisture and } \\
\text { texture }\end{array}$ & $\begin{array}{l}\text { Approximate } \\
\text { age (years) }\end{array}$ \\
\hline \multirow[t]{15}{*}{$\begin{array}{l}\text { Lithuanian } \\
\text { Lakeland }\end{array}$} & Las Garbaski & $\begin{array}{l}54^{\circ} 08.092^{\prime} \mathrm{N} / 22^{\circ} 36.597^{\prime} \mathrm{E} \\
178 \mathrm{~m} \text { a.s.l. }\end{array}$ & Forest clearing & Mesic, sand & $<5$ \\
\hline & Dąbrowskie & $\begin{array}{l}54^{\circ} 06.280^{\prime} \mathrm{N} / 22^{\circ} 33.415^{\prime} \mathrm{E} \\
189 \mathrm{~m} \text { a.s.l. }\end{array}$ & Roadside slope & Mesic, sand & $5-10$ \\
\hline & Pieńki, near Możne & $\begin{array}{l}54^{\circ} 03.585^{\prime} \mathrm{N} / 22^{\circ} 30.525^{\prime} \mathrm{E} \\
175 \mathrm{~m} \text { a.s.l. }\end{array}$ & Roadside ditch & Mesic, sand & $<5$ \\
\hline & Możne & $\begin{array}{l}54^{\circ} 03.230^{\prime} \mathrm{N} / 22^{\circ} 30.981^{\prime} \mathrm{E} \\
171 \mathrm{~m} \text { a.s.l. }\end{array}$ & Abandoned field & Mesic, sand & $>10$ \\
\hline & Gołdap & $\begin{array}{l}54^{\circ} 17.897^{\prime} \mathrm{N} / 22^{\circ} 18.671^{\prime} \mathrm{E} \\
169 \mathrm{~m} \text { a.s.l. }\end{array}$ & Abandoned field & Mesic, sand & $5-10$ \\
\hline & $\begin{array}{l}\text { Suwałki, near } \\
\text { Bród Mały }\end{array}$ & $\begin{array}{l}54^{\circ} 06.094^{\prime} \mathrm{N} / 22^{\circ} 53.308^{\prime} \mathrm{E} \\
174 \mathrm{~m} \text { a.s.l. }\end{array}$ & Abandoned field & Mesic, sand & $5-10$ \\
\hline & Górne & $\begin{array}{l}54^{\circ} 15.672^{\prime} \mathrm{N} / 22^{\circ} 26.507^{\prime} \mathrm{E} \\
180 \mathrm{~m} \text { a.s.l. }\end{array}$ & Abandoned field & Mesic, sand & $5-10$ \\
\hline & Near Ostrowo & $\begin{array}{l}54^{\circ} 16.935^{\prime} \mathrm{N} / 22^{\circ} 27.208^{\prime} \mathrm{E} \\
181 \mathrm{~m} \text { a.s.l. }\end{array}$ & Roadside slope & Mesic, sand & $<5$ \\
\hline & Near Pluszkiejmy & $\begin{array}{l}54^{\circ} 17.393^{\prime} \mathrm{N} / 22^{\circ} 27.731^{\prime} \mathrm{E} \\
194 \mathrm{~m} \text { a.s.l. }\end{array}$ & Abandoned field & Mesic, sand & $5-10$ \\
\hline & Suwałki NE & $\begin{array}{l}54^{\circ} 07.351^{\prime} \mathrm{N} / 22^{\circ} 57.010^{\prime} \mathrm{E} \\
179 \mathrm{~m} \text { a.s.l. }\end{array}$ & Abandoned field & Mesic, sand & $5-10$ \\
\hline & $\begin{array}{r}\text { Suwałki, near } \\
\text { Czarnoziem }\end{array}$ & $\begin{array}{l}54^{\circ} 07.466^{\prime} \mathrm{N} / 22^{\circ} 57.417^{\prime} \mathrm{E} \\
186 \mathrm{~m} \text { a.s.l. }\end{array}$ & Abandoned field & Mesic, sand & $>10$ \\
\hline & Bakałarzewo & $\begin{array}{l}54^{\circ} 05.997^{\prime} \mathrm{N} / 22^{\circ} 39.453^{\prime} \mathrm{E} \\
172 \mathrm{~m} \text { a.s.l. }\end{array}$ & Abandoned field & Mesic, sand & $5-10$ \\
\hline & $\begin{array}{l}\text { Kotowina, near } \\
\text { Karasiewo }\end{array}$ & $\begin{array}{l}54^{\circ} 03.757^{\prime} \mathrm{N} / 22^{\circ} 40.525^{\prime} \mathrm{E} \\
162 \mathrm{~m} \text { a.s.l. }\end{array}$ & Abandoned field & Mesic, sand & $5-10$ \\
\hline & Taciewo & $\begin{array}{l}54^{\circ} 09.339^{\prime} \mathrm{N} / 22^{\circ} 48.464^{\prime} \mathrm{E} \\
204 \mathrm{~m} \text { a.s.l. }\end{array}$ & Abandoned field & Mesic, sand & $5-10$ \\
\hline & Mieruniszki & $\begin{array}{l}54^{\circ} 10.722^{\prime} \mathrm{N} / 22^{\circ} 53.727^{\prime} \mathrm{E} \\
173 \mathrm{~m} \text { a.s.l. }\end{array}$ & Tree plantation & Mesic, sand & $5-10$ \\
\hline \multirow[t]{6}{*}{$\begin{array}{l}\text { Silesian-Kraków } \\
\text { Upland }\end{array}$} & Czajowice & $\begin{array}{l}50^{\circ} 11.172^{\prime} \mathrm{N} / 19^{\circ} 48.434^{\prime} \mathrm{E} \\
435 \mathrm{~m} \text { a.s.l. }\end{array}$ & Abandoned field & Mesic, clay, & $5-10$ \\
\hline & Czajowice & $\begin{array}{l}50^{\circ} 11.431^{\prime} \mathrm{N} / 19^{\circ} 48.567^{\prime} \mathrm{E} \\
438 \mathrm{~m} \text { a.s.l. }\end{array}$ & Abandoned field & Mesic, clay & $5-10$ \\
\hline & Kraków (Mydlniki) & $\begin{array}{l}50^{\circ} 05.291^{\prime} \mathrm{N} / 19^{\circ} 50.603^{\prime} \mathrm{E} \\
234 \mathrm{~m} \text { a.s.l. }\end{array}$ & $\begin{array}{l}\text { Disused limestone } \\
\text { quarry }\end{array}$ & $\begin{array}{l}\text { Dry, mesic, } \\
\text { limestone, sand }\end{array}$ & $>10$ \\
\hline & Near Wolbrom & $\begin{array}{l}50^{\circ} 22.144^{\prime} \mathrm{N} / 19^{\circ} 44.715^{\prime} \mathrm{E} \\
395 \mathrm{~m} \text { a.s.l. }\end{array}$ & Abandoned field & $\begin{array}{l}\text { Dry, mesic, sand, } \\
\text { limestone }\end{array}$ & $5-10$ \\
\hline & Podchybie & $\begin{array}{l}50^{\circ} 19.408^{\prime} \mathrm{N} / 19^{\circ} 45.146^{\prime} \mathrm{E} \\
392 \mathrm{~m} \text { a.s.l. }\end{array}$ & Abandoned field & Mesic, sand & $5-10$ \\
\hline & Rudno & $\begin{array}{l}50^{\circ} 05.625^{\prime} \mathrm{N} / 19^{\circ} 34.087^{\prime} \mathrm{E} \\
318 \mathrm{~m} \text { a.s.l. }\end{array}$ & Abandoned field & Mesic, clay & $<5$ \\
\hline
\end{tabular}


Table 1 continued

\begin{tabular}{|c|c|c|c|c|c|}
\hline \multirow[t]{2}{*}{ Region } & \multirow[t]{2}{*}{ Locality } & \multirow{2}{*}{$\begin{array}{l}\text { GPS coordinates and } \\
\text { altitude }\end{array}$} & \multicolumn{3}{|l|}{ Habitat } \\
\hline & & & Type & $\begin{array}{l}\text { Soil moisture and } \\
\text { texture }\end{array}$ & $\begin{array}{l}\text { Approximate } \\
\text { age (years) }\end{array}$ \\
\hline \multirow[t]{6}{*}{$\begin{array}{l}\text { Lesser Poland } \\
\text { Upland }\end{array}$} & Near Januszowice & $\begin{array}{l}50^{\circ} 15.315^{\prime} \mathrm{N} / 20^{\circ} 02.585^{\prime} \mathrm{E} ; \\
288 \mathrm{~m} \text { a.s.l. }\end{array}$ & Abandoned field & $\begin{array}{l}\text { Dry, mesic, clay, } \\
\text { limestone }\end{array}$ & $5-10$ \\
\hline & Near Januszowice & $\begin{array}{l}50^{\circ} 15.417^{\prime} \mathrm{N} / 20^{\circ} 02.976^{\prime} \mathrm{E} ; \\
263 \mathrm{~m} \text { a.s.l. }\end{array}$ & Roadside slope & Mesic, clay & $<5$ \\
\hline & Near Lipna Wola & $\begin{array}{l}50^{\circ} 15.611^{\prime} \mathrm{N} / 20^{\circ} 02.158^{\prime} \mathrm{E} ; \\
267 \mathrm{~m} \text { a.s. } 1 .\end{array}$ & Abandoned field & Mesic, clay & $5-10$ \\
\hline & Near Książ Wielki & $\begin{array}{l}50^{\circ} 26.134^{\prime} \mathrm{N} / 20^{\circ} 07.875^{\prime} \mathrm{E} ; \\
262 \mathrm{~m} \text { a.s.l. }\end{array}$ & Tree plantation & Mesic, clay & $5-10$ \\
\hline & Podleśna Wola & $\begin{array}{l}50^{\circ} 24.704^{\prime} \mathrm{N} / 20^{\circ} 00.923^{\prime} \mathrm{E} \\
343 \mathrm{~m} \text { a.s.l. }\end{array}$ & Roadside slope & Mesic, clay & $5-10$ \\
\hline & $\begin{array}{l}\text { Near Podleśna } \\
\text { Wola }\end{array}$ & $\begin{array}{l}50^{\circ} 24.487^{\prime} \mathrm{N} / 20^{\circ} 01.201^{\prime} \mathrm{E} ; \\
381 \mathrm{~m} \text { a.s.l. }\end{array}$ & Abandoned field & Mesic, clay & $5-10$ \\
\hline \multirow[t]{5}{*}{$\begin{array}{l}\text { West-Beskidian } \\
\text { Piedmont }\end{array}$} & Lanckorona & $\begin{array}{l}49^{\circ} 51.540^{\prime} \mathrm{N} / 19^{\circ} 43.917^{\prime} \mathrm{E} \\
358 \mathrm{~m} \text { a.s.l. }\end{array}$ & Abandoned field & Mesic, clay & $5-10$ \\
\hline & Głogoczów & $\begin{array}{l}49^{\circ} 54.690^{\prime} \mathrm{N} / 19^{\circ} 52.338^{\prime} \mathrm{E} \\
245 \mathrm{~m} \text { a.s.l. }\end{array}$ & Abandoned field & Mesic, clay & $5-10$ \\
\hline & Palcza & $\begin{array}{l}49^{\circ} 49.231^{\prime} \mathrm{N} / 19^{\circ} 44.633^{\prime} \mathrm{E} \\
541 \mathrm{~m} \text { a.s.l. }\end{array}$ & Abandoned field & Mesic, clay & $5-10$ \\
\hline & Palcza & $\begin{array}{l}49^{\circ} 49.485^{\prime} \mathrm{N} / 19^{\circ} 44.413^{\prime} \mathrm{E} \\
478 \mathrm{~m} \text { a.s.l. }\end{array}$ & Abandoned field & Mesic, clay & $5-10$ \\
\hline & Palcza & $\begin{array}{l}49^{\circ} 49.612^{\prime} \mathrm{N} / 19^{\circ} 44.322^{\prime} \mathrm{E} \\
471 \mathrm{~m} \text { a.s.l. }\end{array}$ & Abandoned field & Mesic, clay & $5-10$ \\
\hline \multirow[t]{2}{*}{ Sandomierz Basin } & Łapczyca & $\begin{array}{l}49^{\circ} 58.167^{\prime} \mathrm{N} / 20^{\circ} 22.624^{\prime} \mathrm{E} \\
257 \mathrm{~m} \text { a.s.l. }\end{array}$ & Roadside slope & Mesic, clay & $<5$ \\
\hline & Łapczyca & $\begin{array}{l}49^{\circ} 58.053^{\prime} \mathrm{N} / 20^{\circ} 21.416^{\prime} \mathrm{E} \\
279 \mathrm{~m} \text { a.s.l. }\end{array}$ & Abandoned field & Mesic, clay & $5-10$ \\
\hline $\begin{array}{l}\text { Central Masovian } \\
\text { Lowland }\end{array}$ & Warszawa Jeziorki & $\begin{array}{l}52^{\circ} 06.888^{\prime} \mathrm{N} / 20^{\circ} 59.502^{\prime} \mathrm{E} \\
104 \mathrm{~m} \text { a.s.l. }\end{array}$ & Abandoned field & Mesic, sand & $5-10$ \\
\hline
\end{tabular}

with $5 \mathrm{ml}$ of sterile water, reaching a $\mathrm{pH}$ value of \pm 7.0 . All Petri dishes with achenes were kept at room temperature $\left(+25^{\circ} \mathrm{C}\right)$, under the 12-h photoperiod $(630 \mathrm{~lx})$. The substrate was complemented with $1 \mathrm{ml}$ of sterile water every other day. The achenes were checked at 1-day intervals counting the germinated seeds up to 21 days from the day of sowing. The seed was determined as germinated when the pericarp of the achene was broken, showing the hypocotyl or cotyledons.

\section{Statistical data analysis}

Normal distribution of the untransformed data concerning the number of (i) vegetative and generative ramets developed from fragments of cluster with a different numbers of stem buds in particular years of the cultivation, (ii) ramet clusters and ramets in populations from different habitats, (iii) ramets in ramet clusters from different habitats, (iv) vegetative and generative ramets in all ramet clusters were tested using the Kolmogorov-Smirnov test, while homogeneity of variance was tested using the Levene test at the significance level of $p<0.05$. Simultaneously, it should be noted that the samples from particular habitats containing only one record were excluded from the analysis.

As the values in some groups (i-iii) were not consistent with normal distribution, and the variance was not homogeneous, the analysis was based mainly on non-parametric tests. The Wilcoxon test for tied pairs was used to test if there were significant differences in the number of descendant ramets grown from the fragments of cluster with the same numbers 
of stem buds among consecutive years of the cultivation, while the Kruskal-Wallis $H$ test with multiple comparisons was applied to check whether there were significant differences in numbers of descendant ramets appearing from the fragments of cluster with different numbers of stem buds in each year of the cultivation separately. Moreover, the Kruskal-Wallis $H$ test with multiple comparisons was also used to test the significance of the differences in the number of ramet clusters and ramets in populations occurring in diverse habitats, and the number of ramets in ramet clusters inhabiting diverse habitats.

As the values of a number of vegetative and generative ramets in all ramet clusters were consistent with normal distribution, and the variance was homogeneous, the parametric $T$-Student test for independent samples was applied to check whether the differences among numbers of generative and vegetative ramets in clusters were significant. Then, the differences in the share of vegetative and generative ramets in ramet clusters growing in different habitats were tested using the $\chi^{2}$ test. Due to a low number of data, the samples from roadside slopes, roadside ditches, and forest clearing were excluded from the analysis. The $\chi^{2}$ test was also applied to check the significance of differences in the percentage of germinated seeds among Solidago $\times$ niederederi, S. canadensis, and $S$. virgaurea, calculated on the basis of four replications of germination test. All statistical analyses were performed using a STATISTICA 12 software package.

\section{Results}

Ramet production and seedling recruitment under cultivation

In the first season of cultivation (2015), the hybrid regrew from the fragments of the cluster with stem buds (groups B, C, and D), whereas all the fragments with removed stem buds died (group A). A total of 17 generative ramets were formed by the hybrid with no sign of vegetative ramet production. In the second season (2016), the hybrid produced a total of 86 ramets, including 84 generative and two vegetative ramets (Table 2). The differences in the number of descendant ramets produced by fragments with the same number of stem buds in 2015 and 2016 were significant only in the group $\mathrm{D}$, according to the results of the Wilcoxon test (Table 2). The differences in the number of descendant generative ramets produced by all fragments with a different number of stem buds in 2015 and 2016 were significant according to the results of the Kruskal-Wallis $H$ test (Table 2); thus, we can accept our hypothesis that after physical fragmentation of a single clone, the number of

Table 2 Number of vegetative and generative ramets produced by Solidago $\times$ niederederi in the garden in 2015-2016

\begin{tabular}{|c|c|c|c|c|c|c|}
\hline \multirow[t]{2}{*}{ Group of plants } & \multicolumn{2}{|c|}{$\begin{array}{l}\text { Mean number } \\
( \pm S D) \text { of vegetative } \\
\text { ramets in the year }\end{array}$} & \multirow[t]{2}{*}{$\begin{array}{l}p \text { value (the } \\
\text { Wilcoxon test) }\end{array}$} & \multicolumn{2}{|c|}{$\begin{array}{l}\text { Mean number }( \pm S D) \text { of } \\
\text { generative ramets in the year }\end{array}$} & \multirow[t]{2}{*}{$\begin{array}{l}p \text { value (the } \\
\text { Wilcoxon test) }\end{array}$} \\
\hline & 2015 & 2016 & & 2015 & 2016 & \\
\hline A & 0 & 0 & - & $0^{\mathrm{a}}$ & $0^{\mathrm{a}}$ & - \\
\hline B & 0 & 0 & - & $\begin{array}{l}1.25^{\mathrm{a}}( \pm 0.43) \\
n=5\end{array}$ & $\begin{array}{l}6.25^{\mathrm{a}}( \pm 0.82) \\
n=25\end{array}$ & 0.06 \\
\hline C & 0 & 0 & - & $\begin{array}{l}1.50^{\mathrm{a}}( \pm 0.50) \\
n=6\end{array}$ & $\begin{array}{l}7.0^{\mathrm{a}}( \pm 4.06) \\
n=28\end{array}$ & 0.10 \\
\hline D & 0 & $\begin{array}{l}0.50( \pm 0.50) \\
n=2\end{array}$ & 0.17 & $\begin{array}{l}1.50^{\mathrm{a}}( \pm 0.50) \\
n=6\end{array}$ & $\begin{array}{l}7.75^{\mathrm{b}}( \pm 2.38) \\
n=31\end{array}$ & $\underline{0.05}$ \\
\hline $\begin{array}{l}p \text { value (the Kruskal-Wallis } \\
H \text { test) }\end{array}$ & - & 0.09 & & $\underline{0.01}$ & $\underline{0.03}$ & \\
\hline
\end{tabular}

The significant values of $p$ are underlined. The same letters in superscripts denote a lack of statistical differences among groups of plants (the Kruskal-Wallis $H$ test for multiple comparisons)

$A$ plants with no stem buds, $B$ plants with one stem bud, $C$ plants with two stem buds, $D$ plants with three stem buds (at the time of planting), $n$ total number of descendant ramets in each group of plants in particular years 
generative ramets increases from one season to another with the number of stem buds located on the caudices. Moreover, the hybrid generated 31 vigorous seedlings (leaf rosettes) which were recognized among the mature plants on August 29, 2016. All leaf rosettes were well developed, showing typical leaf features with no abnormalities. Their progressive growth was observed to the end of the season 2016.

\section{Ramet production in the wild}

The greatest number of ramet clusters per population was recorded in the tree plantations and abandoned fields where it achieved 16.5 and 15.7 on average, respectively, while the smallest population was recorded in the forest clearing where only one ramet cluster occurred. The number of ramets per population presented a quite similar tendency and amounted from 119.2 on average in the abandoned fields to two ramets in the forest clearing (Fig. 1). The mean number of ramets per cluster did not differ remarkably among habitats $(H=6.5, p=0.163)$; therefore, we must reject our hypothesis that the clusters occurring on abandoned fields include more ramets than clusters in other habitats. Altogether, the mean number of vegetative ramets per cluster reached 0.85 , while the generative ones achieved 6.43 on average. The statistical analysis proved that aforementioned differences are significant $(t=-12.6, p=0.0002)$. Therefore, we can accept our hypothesis that the share of generative ramets in clusters is higher than vegetative ones in hybrid populations. The detailed data of the mean numbers of ramets in clusters occurring in

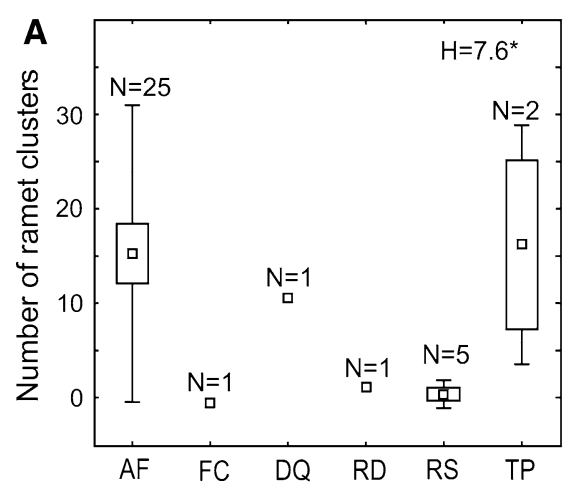

Fig. 1 Number of ramet clusters (A) and ramets (B) in abandoned field (AF), forest clearing (FC), disused quarry (DQ), roadside ditch (RD), roadside slope (RS), and tree plantation (TP). Box and whisker plots give the mean (square), particular habitats are given in Table 3. The remarkably greater share of generative ramets than vegetative ones was revealed in abandoned fields, disused quarry, and tree plantations (Fig. 2).

Seed germination test results

The seed germination test revealed that seeds of Solidago $\times$ niederederi, $S$. canadensis, and $S$. virgaurea are able to germinate with a high percentage (91.0, 80.5 , and $99.5 \%$ on average, respectively). However, our hypothesis that the hybrid seeds germinate with a lower percentage than seeds of its parental species must be rejected because the final germination percentage in the hybrid was significantly lower only in comparison to S. virgaurea (Fig. 3).

\section{Discussion}

The short-term observations in the garden suggest that the stem buds located on caudices are essential for Solidago $\times$ niederederi persistence and ramet production, and their number in a single clone can effectively increase from one season to another. The low number of descendant ramets in the first season of cultivation can be explained by the stress caused by replantation and fragmentation of the cluster, as well as by the small size of the clone fragments. According to Szymura and Szymura (2015), the ramet production in S. canadensis and S. virgaurea delivered from seeds was also relatively low in the first year of cultivation, but it was gradually increasing with increasing size of

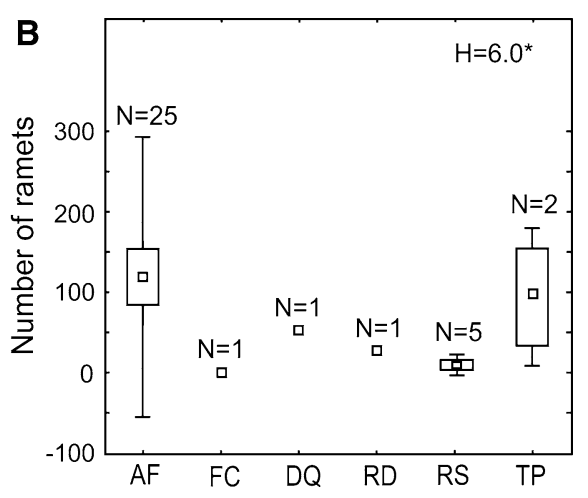

SE (box), and SD (whiskers). $N$ number of populations, $H$ value of Kruskal-Wallis $H$ test (among habitats, where at least 2 populations were observed), *statistical significance at the level $p<0.05$ 
Table 3 The total number of ramet clusters and the mean number of vegetative and generative ramets recorded in Solidago $\times$ niederederi populations from different habitats in the wild

\begin{tabular}{lllll}
\hline $\begin{array}{l}\text { Type of } \\
\text { habitat }\end{array}$ & $\begin{array}{l}\text { Total number of } \\
\text { ramet clusters }\end{array}$ & $\begin{array}{l}\text { Mean number of ramets }( \pm \mathrm{SD}) \\
\text { per ramet cluster }\end{array}$ & $\begin{array}{l}\text { Mean number of vegetative } \\
\text { ramets }( \pm \mathrm{SD})\end{array}$ & $\begin{array}{l}\text { Mean number of generative } \\
\text { ramets }( \pm \mathrm{SD})\end{array}$ \\
\hline $\begin{array}{l}\text { Abandoned } \\
\text { field }\end{array}$ & 413 & $7.6( \pm 10.0)$ & $0.9( \pm 1.8)$ & $6.7( \pm 8.2)$ \\
$\begin{array}{c}\text { Tree } \\
\text { plantation }\end{array}$ & 33 & $6.1( \pm 6.4)$ & $0.7( \pm 1.0)$ & $3.4( \pm 5.4)$ \\
$\begin{array}{c}\text { Disused } \\
\text { quarry }\end{array}$ & 14 & $3.8( \pm 0.6)$ & $0.4( \pm 0.3)$ & $4.5( \pm 3.6)$ \\
$\begin{array}{c}\text { Roadside } \\
\text { slope }\end{array}$ & 10 & $5.0( \pm 4.5)$ & 0 & $9.7( \pm 2.4)$ \\
$\begin{array}{c}\text { Roadside } \\
\text { ditch }\end{array}$ & 3 & $9.7( \pm 2.4)$ & 0 & $2.0( \pm 0.0)$ \\
$\begin{array}{c}\text { Forest } \\
\text { clearing }\end{array}$ & 1 & $2.0( \pm 0.0)$ & & \\
\hline
\end{tabular}

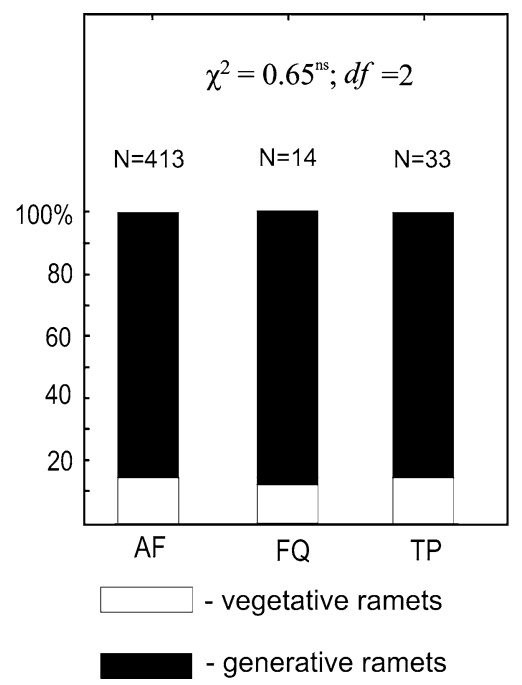

Fig. 2 Mean share of vegetative and generative ramets in ramet clusters in abandoned field (AF), disused quarry (DQ), and tree plantation (TP). $N$ number of ramet clusters, $\chi^{2}$ value of the $\chi^{2}$ test, $d f$ number of degrees of freedom, $n s$ not significant differences

the clones during the next years. Moreover, a physical separation of ramets from a single clone, which was arranged in the garden experiment, seems to be a good way of vegetative reproduction; however, it must be confirmed as a spontaneous process in the wild. Hypothetically, it may happen by animal (e.g., wild boar rooting) and human activities (e.g., plowing of abandoned fields, construction or modernization of roads).

Garden observations as well as seed germination test revealed that the hybrid is able to generate its own

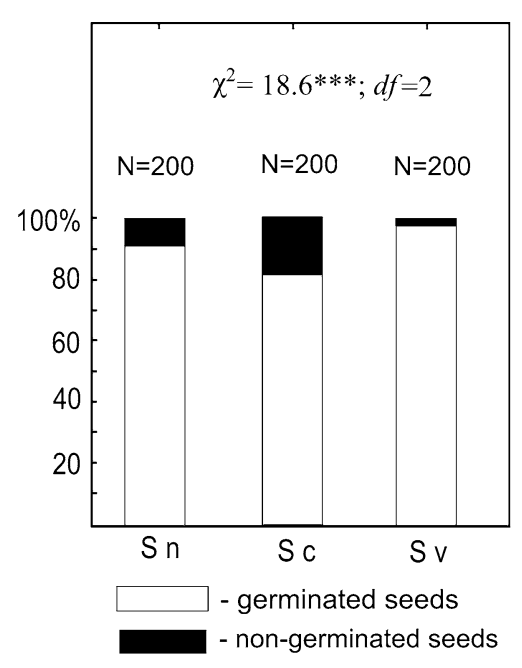

Fig. 3 The final percentage of germinated and non-germinated seeds of Solidago $\times$ niederederi $(\mathrm{Sn}), S$. canadensis $(\mathrm{Sc})$, and $S$. virgaurea $(\mathrm{Sv})$ after 21-day observation in laboratory conditions, calculated on the basis of four replications. $N$ total number of seeds, $\chi^{2}$ value of the $\chi^{2}$ test, $d f$ number of degrees of freedom, $* * *$ statistical significance at the level $p<0.001$

offspring by sexual reproduction. A high value of the final germination percentage in the seed germination test achieved for $S$. × niederederi (Fig. 3) suggests that it has the potential for successful establishment. The seed germination in $S . \times$ niederederi was confirmed by Pagitz (2016); however, he revealed a lower germination rate at a value of $31 \%$. Nevertheless, what is interesting is that the hybrid produces more welldeveloped achenes when a cross-pollination is involved (Pagitz 2016). This statement highlights the 
importance of abundant co-occurrence of mating partners for hybrid sexual reproduction success.

At the same time, it should be noted that the final germination percentage observed in the laboratory might not prejudge reproduction success in the wild, where seedling recruitment and establishment might be hindered or enhanced by habitat conditions. So far, many experiments have proven that plant cover and litter layer contribute to the limitation of seedling appearance in S. canadensis (Goldberg and Werner 1983; Kostrakiewicz-Gierałt 2014) and S. virgaurea (Pietikäinen et al. 2005), while soil microbes enhance the recruitment of their seedlings (Pietikäinen et al. 2005; Sun and He 2010). Moreover, it was proved that the recruitment and growth of seedlings of S. virgaurea might be influenced by the time of seed sowing (Kołodziej 2008) and level of UV-B radiation (Nakajima et al. 2001). In light of the aforementioned findings, it might be stated that there is a need for further study on the seedling recruitment as well as soil seed bank of $S$. $\times$ niederederi in the wild.

The observed diminishing number of populations, ramet clusters, and ramets of $S . \times$ niederederi from the abandoned field, via tree plantation, to the roadside slope, disused quarry, roadside ditch, and forest clearing (Table 3; Fig. 1) suggest the most successful establishment occurred in the abandoned fields. Simultaneously, it is worth mentioning that both parental species also show effective colonization of abandoned fields (Guzikowa and Maycock 1986; Tokarska-Guzik 2005; Lu et al. 2007; Priede 2008; Szymura and Szymura 2011; Karpavičienè et al. 2015; Dyderski and Jagodziński 2016; Szymura and Szymura 2016). The low number of hybrid ramet clusters observed mainly in the forest clearing, roadside ditches, and on the roadside slopes suggests the early stage of colonization, which can be explained by the young age of the habitat or relatively recent disturbance in the habitat (e.g., deforestation, modernization of roads).

The performed observations on the number of ramets per cluster in $S . \times$ niederederi populations (Table 3) confirm effective production of aboveground units in all the studied habitats. It should be mentioned that the expansion of ramet clusters through the production of daughter ramets in $S$. canadensis and $S$. virgaurea begins at the end of their first year of growth (Szymura and Szymura 2015). Similarly, field observations on S. canadensis proved considerable clonal growth of ramet clusters in various site conditions (Bradbury 1981; Hartnett and Bazzaz 1983, 1985). The substantial vegetative spread of alien Solidago species enables their domination in plant communities or even leads to the formation of dense monospecific stands (Jakobs et al. 2004). Moreover, according to Lei (2010) and Witte and Stöcklin (2010), the capability of vigorous asexual reproduction belongs to the most important traits assuring the persistence of clonal plant populations in occupied areas. As such, the vegetative multiplication of aboveground units might be considered as an important component of the establishment strategy of S. $\times$ niederederi.

At the same time, it should be pointed out that in all clusters of $S . \times$ niederederi observed in the field, as well as in the garden, the generative ramets were represented much more abundantly than the vegetative ones (Table 2; Fig. 2). Hitherto observations on genets of $S$. canadensis showed the moderate allocation in generative stems, while in individuals of $S$. gigantea Aiton and S. altissima L., the share of generative stems was much lower than vegetative ones (Schmid et al. 1988). The aforementioned authors also highlighted that the number of inflorescences, flowers, and fruits was greater in $S$. canadensis than in the remaining congeners. In reference to this, it might be concluded that, despite the reduced fruit set in populations of $S . \times$ niederederi (Nilsson 1976; Migdałek et al. 2014; Karpavičienè and Radušienè 2016), the considerable production of sexual ramets might increase the chance of seedling recruitment within an occupied area significantly contributing to the establishment success, as well as enhancing the dispersal and colonization of other habitats.

According to Zhang and Zhang (2007), the great investment in generative ramets in clonal plants is particularly advantageous in environments with a high level of intra- or interspecific competition, where production of numerous seeds enhances the chances for long-distance migration in new, perhaps more favorable sites. On the contrary, other authors (Loehle 1987; Gardner and Mangel 1999) predicted that clonal plants should increase sexual reproduction in noncrowded habitats. At the same time, it is worth mentioning that resource allocation in generative reproduction might be also influenced by other factors such as plant size and population age. Numerous investigations have confirmed that in small populations 
being in the early stage of colonization, the investment in generative ramets is much greater than in established ones. Such a scenario was found in several taxa inter alia in Geum reptans L. (Pluess and Stöcklin 2005), Rumex acetosella L. (Houssard and Escarre 1995), and Sparganium erectum L. emend. Rchb. (Piquot et al. 1998).

In summary, the sexual ramet production in $S . \times$ niederederi occurs in various habitats, including garden conditions; however, abandoned fields seem to be the most suitable for hybrid establishment. A high percentage of germinated seeds in the hybrid suggests its ability to form self-replacing populations. A further study on hybrid population dynamics is strongly recommended to confirm its invasive potential.

Acknowledgements We would like to thank two anonymous reviewers for their valuable suggestions and comments. Field surveys were financially supported by the Jagiellonian University in Kraków (DS/MND/WBiNoZ/IB/19/2013, DS/ MND/WBiNoZ/IB/2/2014, DS/MND/WBiNoZ/IB/2/2015).

Open Access This article is distributed under the terms of the Creative Commons Attribution 4.0 International License (http:// creativecommons.org/licenses/by/4.0/), which permits unrestricted use, distribution, and reproduction in any medium, provided you give appropriate credit to the original author(s) and the source, provide a link to the Creative Commons license, and indicate if changes were made.

\section{References}

Baskin CC, Baskin JM (2014) Seeds: ecology, biogeography and evolution of dormancy and germination, 2nd edn. Academic Press/Elsevier, San Diego

Bradbury IK (1981) Dynamics, structure and performance of shoot populations of the rhizomatous herb Solidago canadensis L. in abandoned pastures. Oecologia 48:271-276. doi:10.1007/BF00347976

Burton R (1980) Solidago $\times$ niederederi Khek in Britain. Watsonia 13:123-124

Dyderski MK, Jagodziński AM (2016) Patterns of plant invasions at small spatial scale correspond with that at the whole country scale. Urban Ecosyst 19:983-998. doi:10. 1007/s11252-015-0524-y

Gardner SN, Mangel M (1999) Modeling investments in seeds, clonal offspring, and translocation in a clonal plant. Ecology 80:1202-1220

Goldberg DE, Werner PA (1983) The effects of size of opening in vegetation and litter cover on seedling establishment of goldenrods (Solidago spp). Oecologia 60:149-155. doi:10. 1007/BF00379516

Gudžinskas Z, Petrulaitis L (2016) New alien plant species recorded in the southern regions of Latvia. Bot Lith 22:153-160. doi:10.1515/botlit-2016-0016
Gudžinskas Z, Žalneravičius E (2016) Solidago $\times$ snarskisii nothosp. Nov. (Asteraceae) from Lithuania and its position in the infrageneric classification of the genus. Phytotaxa 253:147-155. doi:10.11646/phytotaxa.253.2.4

Guzikowa M, Maycock PF (1986) The invasion and expansion of three North American species of goldenrod (Solidago canadensis L. sensu lato, S. gigantea Ait. and Solidago graminifolia (L.) Salisb.) in Poland. Acta Soc Bot Pol 55:367-384

Hartnett DC, Bazzaz FA (1983) Physiological integration among intraclonal ramets in Solidago canadensis. Ecology 64:779-788. doi:10.2307/1937201

Hartnett DC, Bazzaz FA (1985) The genet and ramet population dynamics of Solidago canadensis in an abandoned field. J Ecol 73:407-413. doi:10.2307/2260483

Houssard C, Escarre J (1995) Variation and covariation among life-history traits in Rumex acetosella from a successional old field gradient. Oecologia 102:70-80. doi:10.1007/ BF00333312

Jakobs G, Weber E, Edwards PJ (2004) Introduced plants of the invasive Solidago canadensis (Asteraceae) are larger and grow denser than conspecifics in the native range. Divers Distrib 10:11-19. doi:10.1111/j.1472-4642.2004.00052.x

Karpavičienè B, Radušienè J (2016) Morphological and anatomical characterization of Solidago $\times$ niederederi and other sympatric Solidago species. Weed Sci 64:61-70. doi:10.1614/WS-D-15-00066.1

Karpavičienè B, Radušienè J, Viltrakytė J (2015) Distribution of two invasive goldenrod species Solidago canadensis and $S$. gigantea in Lithuania. Bot Lith 21:125-132. doi:10.1515/ botlit-2015-0015

Kołodziej B (2008) Effect of agrotechnical factors on the yield of goldenrod (Solidago virgaurea L. ssp. virgaurea). Herb Polonica 54:28-34

Kostrakiewicz-Gierałt K (2014) The effects of successional stage and size of gaps on recruitment of clonal plants in overgrowing. Acta Agrobot 67:87-98. doi:10.5586/aa. 2014.044

Lei S (2010) Benefits and costs of vegetative and sexual reproduction in perennial plants: a review of literature. J Ariz-Nev Acad Sci 42:9-14. doi:10.2181/036.042.0103

Loehle C (1987) Partitioning of reproductive effort in plants: a cost-benefit model. Oikos 49:199-208

Lu JZ, Weng ES, Wu XW, Weber E, Zhao B, Li B (2007) Potential distribution of Solidago canadensis in China. Acta Phytotax Sin 45:670-674. doi:10.1360/aps06200

Migdałek G, Kolczyk J, Pliszko A, Kościńska-Pająk M, Słomka A (2014) Reduced pollen viability and achene development in Solidago $\times$ niederederi Khek from Poland. Acta Soc Bot Pol 83:251-255. doi:10.5586/asbp.2014.025

Nakajima N, Takahashi S, Tamaoki M, Kubo A, Aono M, Saji H (2001) Effects of UV-B radiation on seedlings of two Solidago virgaurea populations from the Mt. Hakusan area of Japan. J Jpn Soc Atmos Environ 36:301-307. doi:10. 11298/taiki1995.36.5_301

Nilsson A (1976) Spontana gullrishybrider (Solidago canadensis $\times$ virgaurea) i Sverige och Danmark. Sven Bot Tidskr 70:7-16

Pagitz K (2016) Solidago $\times$ niederederi (S. canadensis $\times S$. virgaurea ssp. virgaurea $)$ in the Eastern Alps. pp. 194. In: Ries C, Krippel Y (eds) Biological invasions: 
interactions with environmental change. Book of abstracts. NEOBIOTA 2016. 9th International Conference on Biological Invasions. Vianden, Luxembourg, 14-16 September 2016, p 256

Pagitz K, Lechner-Pagitz C (2015) Neues zur Neophytenflora Nord- und Osttirols (Österreich). Neilreichia 7:29-44

Pietikäinen A, Kytöviita M-M, Vuoti U (2005) Mycorrhiza and seedling establishment in a subarctic meadow: effects of fertilization and defoliation. J Veg Sci 16:175-182

Piquot Y, Petit D, Valero M, Cuguen J, De Laguerie P, Vernet P (1998) Variation in sexual and asexual reproduction among young and old populations of the perennial macrophyte Sparganium erectum. Oikos 82:139-148. doi:10.2307/ 3546924

Pliszko A (2013) A new locality of Solidago $\times$ niederederi Khek (Asteraceae) in Poland. Biodiv Res Conserv 29:57-62. doi:10.2478/biorc-2013-0008

Pliszko A (2015) Neotypification of Solidago $\times$ niederederi (Asteraceae). Phytotaxa 230:297-298. doi:10.11646/ phytotaxa.230.3.10

Pliszko A, Jaźwa M (2017) Floristic composition of vegetation in habitats suitable for Erigeron $\times$ huelsenii (Asteraceae). Acta Bot Croat 76:9-14. doi:10.1515/botcro-2016-0040

Pliszko A, Zając M (2016) Current and potential distribution of Solidago $\times$ niederederi (Asteraceae) in Poland. pp. 163 . In: Ries C, Krippel Y (eds) Biological invasions: interactions with environmental change. Book of abstracts. NEOBIOTA 2016. 9th International Conference on Biological Invasions. Vianden, Luxembourg, 14-16 September 2016, p 256

Pliszko A, Zalewska-Gałosz J (2016) Molecular evidence for hybridization between invasive Solidago canadensis and native $S$. virgaurea. Biol Invasions 18:3103-3108. doi:10. 1007/s10530-016-1213-3

Pluess AR, Stöcklin J (2005) The importance of population origin and environment on clonal and sexual reproduction in the alpine plant Geum reptans. Funct Ecol 19:228-237. doi:10.1111/j.0269-8463.2005.00951.x

Priede A (2008) Invasive non-native Solidago species in Latvia: expansion history and current distribution. Proc Latv Acad Sci B 62:78-83. doi:10.2478/v10046-008-0003-4

Pyšek P, Richardson DM, Rejmánek M, Webster GL, Williamson M, Kirschner J (2004) Alien plants in checklists and floras: towards better communication between taxonomists and ecologists. Taxon 53:131-143

Richardson DM, Pyšek P (2012) Naturalization of introduced plants: ecological drivers of biogeographical patterns. New Phytol 196:383-396. doi:10.1111/j.1469-8137.2012. 04292.x
Richardson DM, Pyšek P, Rejmánek M, Barbour MG, Panetta FD, West CJ (2000) Naturalization and invasion of alien plants: concepts and definitions. Diver Distr 6:93-107

Schmid B, Puttick GM, Burgess KH, Bazzaz FA (1988) Correlations between genet architecture and some life history features in three species of Solidago. Oecologia 75:459-464. doi:10.1007/BF00376952

Stace CA, Preston CD, Pearman DA (2015) Hybrid flora of the British Isles. Botanical Society of Britain and Ireland, Bristol

Sun ZK, He WM (2010) Evidence for enhanced mutualism hypothesis: Solidago canadensis plants from regular soils perform better. PLoS ONE 5(11):e15418. doi:10.1371/ journal.pone.0015418

Sunding P (1989) Naturaliserte Solidago-(gullris-) arter i Norge. Blyttia 47:23-27

Szymura M, Szymura TH (2011) Rozmieszczenie nawłoci (Solidago spp.) na obszarze Dolnego Śląska oraz ich wpływ na różnorodność biologiczną zasiedlanych fitocenoz. Acta Bot Siles 6:195-212

Szymura M, Szymura TH (2015) The dynamics of growth and flowering of invasive Solidago species. Steciana 19:143-152. doi:10.12657/steciana.019.016

Szymura M, Szymura T (2016) Historical contingency and spatial processes rather than ecological niche differentiation explain the distribution of invasive goldenrods ( $\mathrm{Sol}$ idago and Euthamia). Plant Ecol 217:565-582. doi:10. 1007/s11258-016-0601-1

Tokarska-Guzik B (2005) The establishment and spread of alien plant species (kenophytes) in the flora of Poland. Wydawnictwo Uniwersytetu Śląskiego, Katowice

van Kleunen M, Dawson W, Essl F, Pergl J, Winter M, Weber E, Kreft H, Weigelt P, Kartesz J, Nishino M, Antonova LA, Barcelona JF, Cabezas FJ, Cárdenas D, Cárdenas-Toro J, Castaño N, Chacón E, Chatelain C, Ebel AL, Figueiredo E, Fuentes N, Groom QJ, Henderson L, Inderjit Kupriyanov A, Masciadri S, Meerman J, Morozova O, Moser D, Nickrent DL, Patzelt A, Pelser PB, Baptiste MP, Poopath M, Schulze M, Seebens H, Shu WS, Thomas J, Velayos M, Wieringa JJ, Pyšek P (2015) Global exchange and accumulation of non-native plants. Nature 525:100-103. doi: $10.1038 /$ nature 14910

Witte LC, Stöcklin J (2010) Longevity of clonal plants: why it matters and how to measure it. Ann Bot 106:859-870. doi:10.1093/aob/mcq191

Zhang Y, Zhang D (2007) Asexual and sexual reproductive strategies in clonal plants. Front Biol China 2:256-262. doi:10.1007/s11515-007-0036-0 